\title{
ANALISIS KESALAHAN SINTAKSIS MAHASISWA DALAM MENULIS PARAGRAF MENGGUNAKAN BAHASA INGGRIS
}

\author{
Yulia Ramadhiyanti \\ IKIP PGRI Pontianak \\ Corresponding Email: yuliaramadhiyanti@yahoo.com
}

Received: 5th of October 2020, Accepted: $19^{\text {th }}$ of November 2020, Published: $24^{\text {th }}$ of December 2020

\begin{abstract}
Abstrak
Tujuan penelitian adalah untuk mengetahui jenis-jenis kesalahan yang dilakukan oleh mahasiswa dalam menulis sebuah paragraf bahasa Inggris dan untuk mengetahui jenisjenis kesalahan yang umumnya banyak dilakukan oleh mahasiswa tersebut. Penelitian menggunakan pendekatan deskriptif kualitatif dengan metode analisis. Teknik pengumpulan data menggunakan observasi dan pengukuran dan alat pengumpulan data menggunakan lembar observasi dan tes tertulis. Hasil analisis menunjukkan bahwa kesalahan-kesalahan yang ditemukan adalah: (1) kategori sintaksis dan strategi permukaan, berupa kesalahan pada noun phrase, verb phrase, transformation, dan miscellanous. Kemudian pada kategori permukaan, jenis-jenis kesalahan yang ditemukan adalah kesalahan penghilangan, penambahan, kesalahan bentuk, kesalahan urutan, dan pensubtitusian. Kesalahan sintaksis yang paling dominan pada tulisan mahasiswa adalah kesalahan pada noun phrase; dan (2) pada kategori taksonomi komunikatif, tidak terdapat kesalahan yang menyeluruh, hanya ditemukan sedikit kesalahan saja, artinya walaupun dalam frase atau kalimat tersebut terdapat kesalahan sintaksis, pesan yang disampaikan masih bisa dimengerti oleh pembaca.
\end{abstract}

Kata Kunci: kesalahan sintaksis, menulis paragraf, bahasa Inggris.

\begin{abstract}
The purposes of this study were to determine the types of errors made by the students in writing an English paragraf and to determine the types of errors that are generally done by the student. This study used a descriptive approach qualitative analysis method. The data processing is done by using observation on a written test as a research instrument. Data analysis showed that the errors found based on: (1) the syntactic category and the strategy of the surface, such as some errors in the noun phrase, verb phrase, transformation, and miscellaneous. Then on the surface of the categories, the types of errors found were errors omissions, additions, misformation, misordering and substitution errors. The most dominant errors in student writing was an error in the noun phrase; and (2) the taxonomy communicative category, there are no errors overall, only found a little mistake, meaning that although the phrase or sentence containing a syntax error, the message can still be understood by readers.
\end{abstract}

Keywords: syntax error, paragraf writing, English.

\section{PENDAHULUAN}

Berbahasa yang baik dan benar merupakan hal terpenting bagi setiap orang agar bisa berkomunikasi dan mengeksplorasi ide-ide pada orang lain. Tanpa berbahasa dengan baik dan benar orang-orang tidak bisa menyampaikan ide-ide dan berinteraksi dengan orang lain secara intensif. Meskipun dalam proses pembe- lajaran bahasa yang baik dan benar terkadang mengalami banyak kesulitan dalam bentuk kesalahan- 
kesalahan berbahasa, namun kesalahan-kesalahan tersebut bukan berarti sesuatu yang negatif bagi para pembelajarnya. Hal tersebut meru-pakan sesuatu yang alami terjadi dalam proses belajar bahasa, dikarenakan pengaruh bahasa pertama yang lebih sering digunakan serta strategi yang digu-nakan dalam pembelajaran bahasa asing. Seperti yang dikatakan oleh Richards (1984: 182) bahwa banyak dari kesalahan para peserta didik terjadi dikarenakan oleh strategi yang mereka gunakan dalam pemerolehan bahasa kedua. Banyak orang-orang yang tertarik untuk belajar bahasa lain selain bahasa yang sehari-hari yang digunakan. Salah satunya yakni bahasa Inggris. Orang-orang tersebut beranggapan bahwa dengan menguasai bahasa Inggris, maka akan dapat bersaing dengan banyak orang dalam mencapai kesuksesan hidup, terutama dalam mempe-roleh pekerjaan.

Salah satu lembaga pendidikan di Indonesia, tepatnya di kota Pontianak Kalimantan Barat, yakni Institut Keguruan Ilmu Pendidikan (IKIP) Persatuan Guru Republik Indonesia (PGRI) Pontianak yang memiliki sepuluh program studi, salah satunya ialah Program Studi Pendidikan Bahasa Inggris. IKIP PGRI Pontianak menjadi salah satu institusi yang diminati banyak siswa yang baru lulus Sekolah Menengah Atas untuk belajar bahasa Inggris lebih mendalam selain memperoleh tambahan ilmu pengetahuan baru sebagai calon guru. IKIP PGRI Pontianak didalam proses penerimaan mahasiswa baru mewajibkan lulus dalam tahap penyeleksian. Tahap seleksi yang terdiri dari seleksi administrasi, seleksi tes tertulis, seleksi tes wawancara, dan seleksi tes praktik. Calon mahasiswa baru khususnya yang ingin memilih Program Studi Pendidikan Bahasa Inggris pada tahap seleksi tes praktik diminta mempraktikkan dua keterampilan produktif awal dalam berbahasa Inggris, yaitu keterampilan berbicara dan keterampilan menulis.

Tahap seleksi tes praktik keterampilan menulis menggunakan bahasa Inggris mahasiswa semester satu tahun akademik 2015/2016, masih banyak mahasiswa yang melakukan kesalahan berbahasa. Kesalahan berbahasa tidak hanya terdapat pada tuturan tetapi juga terdapat pada bahasa tertulis. Hal tersebut ditinjau dari ragam bahasa berdasarkan sarana pemakaiannya yaitu ragam lisan dan tulis. Bahasa tertulis terikat pada aturan-aturan kebahasaan, seperti ejaan, susunan, sistematika, dan teknik-teknik penulisan. Apabila mahasiswa tidak memenuhi aturan-aturan kebahasaan tertulis, terjadilah kesalahan kebahasaan. Salah satu kesalahan kebahasaan tertulis yang masih sering dilakukan mahasiswa adalah kesalahan sintaksis. Ruang lingkup kesalahan sintaksis berkisar pada kesalahan diksi, frasa, klausa, dan kalimat berikut alat-alat 
sintaksis yang membentuk unsur-unsur tersebut. Kesalahan bahasa pada dasarnya disebabkan pada diri orang yang menggu-nakan bahasa yang bersangkutan bukan pada bahasa yang digunakannya. Ada tiga kemungkinan penyebab seseorang dapat salah dalam berbahasa, yaitu: (1) ter-pengaruh bahasa yang lebih dahulu dikuasainya; (2) kekurangpahaman pemakai bahasa terhadap bahasa yang dipakainya; dan (3) pengajaran bahasa yang kurang tepat atau sempurna.

Analisis kesalahan merupakan proses yang didasarkan pada analisis kesalahan orang yang sedang belajar dengan objek (yaitu bahasa) yang sudah ditargetkan. Bahasa yang ditargetkan dapat berupa bahasa ibu maupun bahasa nasional dan bahasa asing. Analisis kesalahan sintaksis dapat mengungkapkan keberhasilan dan kegagalan program pembelajaran yang dirancang oleh dosen. Analisis kesalahan sintaksis juga dapat digunakan sebagai alat untuk mengukur kemampuan berbahasa peserta didik pada umumnya. Hasil dari analisis kesalahan sintaksis dapat digunakan sebagai bahan untuk menerangkan bagian-bagian kesalahan sintaksis yang sering dilakukan mahasiswa, sehingga untuk selanjutnya kesalahan yang serupa dapat dikurangi.

Kesalahan berbahasa dalam pembelajaran bahasa merupakan suatu hal yang tidak bisa dihindari. Kesalahan seseorang dalam berbahasa dapat menjadi masalah jika orang tersebut mengerti tentang konsep kesalahan, namun sebaliknya bisa menjadi hal sederhana jika orang tersebut tidak menyadari akan kesalahannya dalam bertindak tutur atau berbahasa. Tarigan (1998) menjelaskan bahwa kesalahan berbahasa tidak hanya dibuat oleh siswa yang mempelajari bahasa kedua (B2), tetapi juga oleh siswa yang mempelajari bahasa pertamanya (B1). Hal tersebut menunjukkan bahwa kesalahan berbahasa erat kaitannya dengan pembelajaran bahasa, baik pembelajaran B1 maupun B2. Oleh karenanya, kesalahan-kesalahan yang terjadi perlu diketahui dan dikaji secara mendalam, sebab kesalahan tersebut merupakan bagian integral dari proses belajar bahasa.

Dengan mengkaji kesalahan-kesalahan tersebut, setidaknya ada tiga informasi yang diperoleh, yaitu: (1) sebagai umpan balik bagi pendidik, sampai sejauh mana kemajuan telah dicapai peserta didik, sehingga materi-materi apa sajakah yang masih tersisa dan harus dipelajari; (2) sebagai bukti bagi peneliti tentang bagaimana seseorang memperoleh dan belajar bahasa; dan (3) sebagai masukan bahwa kesalahan tersebut merupakan salah satu strategi yang digunakan siswa dalam memperoleh bahasanya (Corder, $1981: 56)$. 
Richards (1984: 187) mengelompokkan kesalahan dalam dua kategori, yaitu kesalahan karena pengaruh unsur bahasa pertama (kesalahan interlingual) dan kesalahan karena kompleksitas bahasa target sendiri (kesalahan intralingual). Selanjutnya Richards membagi kesalahan intralingual dalam empat macam, yaitu: (1) overgeneralization, yaitu kesalahan yang disebablkan oleh generalisasi unsur- unsur bahasa target secara berlebihan; (2) iqnore of rule restrictions, yaitu kesalahan yang disebabkan pembelajar mengabaikan pembatasan kaidah-kaidah bahasa target; (3) incomplete application of rules, yaitu kesalahan penerapan kaidah bahasa target yang tidak sempurna; dan (4) false concept, yaitu kesalahan dalam membuat hipotesis terhadap konsep kaidah bahasa target.

Selinker (1972: 245) mengklasifikasikan kesalahan berbahasa dalam lima klasifikasi berdasarkan sumber penyebabnya, yaitu: (1) overgeneralization of target rules, yaitu kesalahan karena adanya generalisasi kaidah bahasa target secara berlebihan; (2) transfer of training, yaitu kesalahan yang terjadi karena prosedur pembelajaran yang tidak tepat; (3) strategy of second language learning, yaitu kesalahan yang terjadi karena pendekatan yang tidak tepat terhadap kaidah bahasa kedua yang dipelajari pembelajar; (4) strategy of second language communication, yaitu kesalahan yang terjadi karena pendekatan yang dilakukan oleh pembelajar dalam berkomunikasi dengan penutur asli (native speaker) yang tidak tepat; dan (5) language transfer, yaitu kesalahan yang terjadi karena pemin-dahan unsur-unsur bahasa pertama yang telah memfosil kedalam bahasa kedua.

Analisis kesalahan berbahasa adalah upaya untuk menginformasikan kesalahankesalahan dalam penggunaan bahasa asing yang memiliki perbedaan dengan bahasa ibu. Kesalahan diartikan sebagai penyimpangan dari aturan-aturan yang berlaku atau sebagai pelanggaran terhadap kaidah tata bahasa yang terjadi karena kesalahpahaman atau kesulitan berkomunikasi (James, 1998: 123). Corder (1981) mengatakan bahwa analisis kesalahan mempunyai dua fungsi dalam proses pembelajaran, yaitu untuk menginvestigasi proses pembelajaran bahasa dan untuk mengetahui apakah pengajaran perlu atau tidak dilakukan agar pencapaian tujuan belajar itu berhasil. Chafe (1982: 87) mengatakan bahwa analisis kesalahan memberikan tiga keuntungan, yaitu: (1) dosen mengetahui seberapa jauh tujuan pembelajaran telah tercapai; (2) analisis kesalahan juga memberikan data dan bukti bagaimana mahasiswa belajar dan strategi apa yang digunakan; dan (3) kesalahan yang dibuat dapat juga sebagai sumber atau materi 
atau bahan untuk belajar berikutnya yang pada gilirannya mahasiswa tahu dan memahami mana yang benar dan mana yang salah.

Brown (2007: 105) mengatakan bahwa analisis kesalahan adalah analisis terhadap kesalahan-kesalahan berbahasa seorang mahasiswa baik bahasa asing, bahasa kedua, ataupun bahasa pada umumnya. Dengan demikian dapat dikatakan bahwa pengertian analisis kesalahan berbahasa adalah suatu proses kerja yang digunakan oleh guru dan peneliti bahasa dengan langkah-langkah pengumpulan data, pengidentifikasian kesalahan yang terdapat dalam data, penjelasan kesalahan tersebut, pengklasifikasian kesalahan berdasarkan penyebabnya, serta peng- evaluasian taraf keseriusan kesalahan itu.

Dulay, Burt, dan Krashen (1982: 138) menyebutkan empat taksonomi deskriptif untuk menganalisis kesalahan, yaitu: (1) linguistic category taxonomy. Kategori yang mengklasifikasikan kesalahan sesuai dengan salah satu atau kedua komponen bahasa (fonologi, sintaksis dan morfologi, semantik dan leksikon, dan gaya) dan konstituen linguistik tertentu lainnya; (2) surface strategy taksonomy. Kesalahan yang berkaitan dengan bagaimana tata bahasa yang mendasar diganti oleh mahasiswa. Omission errors adalah tidak adanya item yang harus muncul dalam berkomunikasi yang benar. Misalnya: there is a doll in my room.

Addition errors adalah kesalahan yang disebabkan adanya item yang tidak seharusnya muncul dalam berkomunikasi dengan benar, ada tiga jenis kesalahan: (a) double markings. Contoh "she didn't went back"; (b) regularization. Contoh "eated for ate, childs for children”; (c) simple additions. Contoh "the fishes doesn't live in the water". Misformation errors adalah kesalahan yang ditandai dengan kesalahan penggunaan bentuk morphim atau struktur. Ada tiga jenis kesalahan: (a) regularization errors. Contoh "the dog eated the chicken"; (b) archi-forms. Contoh "I see her yesterday" dan "Her dance with my brother"; (c) alternating forms. Contoh "I seen her yesterday". Misordering errors adalah kesalahan penempatan sebuah morphim atau sekelompok morphem dalam komunikasinya. Misalnya "I don't know what is that"; (3) comparative taxonomy adalah mengklasifikasikan kesalahan berdasarkan perbandingan antara struktur yang digunakan oleh peserta didik dan konstruksi jenis tertentu lainnya. Kesalahan diklasifikasikan kedalam developmental errors, interlingual errors, ambiguous errors, and unique errors; dan (4) communicative effect taxonomy adalah kesalahan dari perspektif efek sebagai pendengar atau pembaca. Taksonomi tersebut mengklasifikasikan kesalahan pada kesalahan global dan lokal. 
Kemampuan atau keterampilan menulis adalah kemampuan mengungkapkan gagasan, pendapat, dan perasaan kepada pihak lain dengan melalui bahasa tulis (Carson, 2001: 56). Ketepatan pengungkapan gagasan harus didukung oleh ketepatan bahasa yang digunakan. Selain komponen kosakata yang gramatikal, ketepatan kebahasaan juga sebaiknya didukung oleh konteks dan penggunaan ejaan. Hal tersebut dapat dikatakan bahwa menulis boleh dikatakan paling sukar dibandingkan keterampilanketerampilan berbahasa lainnya, apabila seorang mahasiswa menggunakan bahasa kedua/asing secara lisan, maka seorang penutur asli dapat mengerti dan menerima lafal yang kurang sempurna atau ungkapan- ungkapan yang gramatikal. Tetapi apabila mahasiswa menggunakan bahasa kedua/asing secara tulisan, maka penutur asli yang membacanya akan lebih keras dalam menilai tulisan yang banyak kesalahan ejaan atau tata bahasanya, meskipun makna yang disampaikan sudah cukup jelas dan tulisannya cukup rapi, tetapi suatu tulisan tersebut harus baik dan sedapat mungkin tanpa kesalahan karena dianggap mencerminkan tingkat pendidikan penulis.

Menulis dalam arti harfiahnya membuat huruf, angka, nama, dan suatu tanda kebahasaan apapun dengan suatu alat tulis pada suatu halaman tertentu. Sebuah kalimat semestinya harus mendukung suatu gagasan atau ide. Susunan kalimat yang sistematis menunjukkan cara berpikir yang teratur. Agar gagasan atau ide mudah dipahami pembaca, fungsi sintaksis yaitu subjek, predikat, objek, pelengkap, dan keterangan harus tampak jelas. Kelima fungsi sintaksis tidak selalu hadir secara bersama-sama dalam sebuah kalimat. Unsur-unsur sebuah kalimat harus dieksplisitkan dan dirakit secara logis dan masuk akal (Carson, 2001). Dalam penelitian yang dilakukan akan dibahas mengenai kesalahan sintaksis. Sintaksis adalah cabang linguistik tentang susunan kalimat dan bagian-bagiannya atau ilmu tata kalimat. Sintaksis berkaitan erat dengan morfologi yang membicarakan seluk- beluk kata dan morphim. Kesalahan dalam tataran sintaksis berhubungan erat dengan kesalahan pada bidang morfologi, karena kalimat berunsurkan kata-kata.

Kesalahan sintaksis berdasarkan beberapa pengertian yang telah dijelaskan adalah kesalahan, penyimpangan, pelanggaran, kekhilafan terhadap suatu kaidah yang ditentukan dalam tataran sintaksis (ilmu bahasa yang membicarakan seluk- beluk frasa, klausa, kalimat atau pengaturan dan hubungan antara kata dengan kata atau dengan satuan-satuan yang lebih besar atau antara satuan-satuan yang lebih besar itu dalam bahasa yang mempunyai satuan terkecil yaitu kata). Richards (1984: 117) menjelaskan bahwa "syntax is the study of how words combine to form sentences and the rules 
which govern the formation of sentences". Richards menjelaskan bahwa sintaks adalah kaidah yang digunakan untuk merangkai kata menjadi frase atau kalimat dan kaidah yang digunakan untuk menganalisis kalimat. Kesalahan sintaksis dalam proses menulis dalam bahasa asing akan berbeda dengan dalam proses menulis dalam bahasa ibu. Faktor penyebabnyapun akan berbeda. Kesalahan sintaksis dalam proses menulis dalam bahasa ibu keseringannya hanya karena faktor kecerobohan atau faktor kesadaran terhadap bahasa rendah. Dalam proses menulis kalimat-kalimat dengan menggunakan bahasa Inggris, kesalahan sintaksis mungkin disebabkan oleh ber-bagai faktor, seperti interferensi dari Bahasa ibu atau juga karena perbedaan kaidah gramatikal antara bahasa ibu dengan bahasa Inggris. Kesalahan sintaksis yang berkaitan dengan ketiadaan subjek sering ditemukan. Hal tersebut merupakan interferensi dari kebiasaan atau kecerobohan pada waktu menulis dalam bahasa ibu.

Kesalahan sintaksis lainnya yang sering ditemukan adalah kesalahan dalam tenses dan pluralizing atau penjamakan nomina maupun verba. Kesalahan sintak- sis tersebut merupakan kesalahan yang berkaitan dengan interferensi dari bahasa ibu karena bahasa Indonesia, misalnya tidak mengenal tenses ataupun pluralizing. Dalam belajar bahasa Inggris, bahasa ibu sedikit banyak akan sangat berpengaruh. Brown (2007: 187) menyatakan bahwa ada dua macam interferensi dari bahasa ibu terhadap pemerolehan bahasa asing, yaitu interfering dan facilitating. Kesa-lahan dalam kategori interferensilah yang menyebabkan terjadinya kesalahan sintaksis. Brown (2007: 26) menyatakan bahwa “.... the native language of every learner is an extremely significant factor in the acquisition of a new language. Most of the time, we think os the native language as exercising an interfering effect on the target language, and indeed the most salient, observable effect does appear to be one of interference. The majority of a learner's error in producing the second language,

... stem from the learner's assumption that the target language operates like the native language”. Dari pernyataan tersebut terlihat jelas bahwa kesalahan sintaksis bisa terjadi karena adanya interferensi dari bahasa ibu sehingga menyebabkan siswa berasumsi bahwa bahasa asing mempunyai kaidah yang sama dengan bahasa ibu. Apabila melihat salah satu penyebab kesalahan sintaksis, kesalahan tersebut keseringannya disebabkan oleh asumsi bahwa bahasa asing mempunyai kaidah yang sama dengan bahasa ibu. 


\section{METODE}

Penelitian yang dilakukan menggunakan pendekatan deskriptif kualitatif dengan metode analisis. Alasannya, penelitian cenderung bersifat deskriptif dan menggunakan analisis. Deskripsi dilakukan terhadap fenomena alami, tanpa intervensi suatu eksperimen atau suatu perlakuan. Penelitian berawal dari data dan dengan memanfaatkan teori yang ada, berakhir dengan teori. Cresswell (1994) mengatakan bahwa penelitian kualitatif bersifat deskriptif karena peneliti tertarik dengan proses, makna, dan pemahaman melalui kata-kata atau gambar. Adapun teknik pengumpulan data dalam penelitian menggunakan teknik observasi dengan tes tertulis mahasiswa sebagai instrumen penelitiannya. Pada tes tertulis, maha- siswa diminta menulis sebuah kalimat dengan menggunakan bahasa Inggris. Tes dilakukan guna mengetahui sampai sejauh mana keterampilan awal menulis paragraf bahasa Inggris mahasiswa baru. Juga guna mengetahui kesalahan- kesalahan yang dibuat oleh mahasiswa berkaitan dengan materi tersebut.

Teknik analisis data yang digunakan adalah deskriptif analisis. Peneliti melakukan identifikasi, deskripsi, dan klasifikasi kesalahan ejaan yang terdapat dalam sebuah kalimat dan selanjutnya menjelaskan sumber-sumber atau penyebab serta dampak komunikatif kesalahan tersebut. Variabel yang akan diteliti adalah variabel tunggal yang bersifat kualitatif, yaitu kesalahan sintaksis dalam menulis paragraf menggunakan bahasa Inggris. Kemudian, populasi penelitian adalah mahasiswa baru IKIP PGRI Pontianak tahun akademik 2015/2016 gelombang pertama, sedangkan sampel yang akan digunakan adalah satu kelas yang dipilih secara acak menggunakan teknik cluster random sampling dari tiga kelas pagi.

\section{HASIL DAN PEMBAHASAN}

Dari 20 tulisan mahasiswa terdapat 128 kalimat yang tidak sesuai dengan kaidah penulisan dan setidaknya terdapat satu kesalahan sintaksis pada tiap kali- mat tersebut. Kesalahan pada tiap-tiap tulisan mahasiswa berbeda-beda, berkisar dari 3 hingga 27 kesalahan. Kesalahan sintaksis yang ditemukan dalam tulisan mahasiwa terbagi dalam empat kategori, yaitu kesalahan pada frase kata benda (noun phrase), frase kata kerja (verb phrase), kesalahan yang berkaitan dengan transformasi struktur frase, klausa, atau kalimat (transformation), serta kesalahan lain yang tergabung dalam kategori miscellaneous.

Kesalahan dalam kategori noun phrase meliputi kesalahan dalam penggunaan determiner, number, pronoun, preposition, dan penggunaan kata benda (noun). 
Kemudian, kesalahan dalam kategori verb phrase meliputi kesalahan dalam struktur pembentukan kalimat dalam present tense, present perfect tense, simple past tense, dan kesalahan struktur karena kekhususan dalam penggunnaan kata kerja tertentu. Dalam kategori transformasi, kesalahannya berpusat pada pembentukan struktur kalimat pasif. Sedangkan, pada kategori miscellaneous kesalahan yang terjadi merupakan kesalahan acak yang berhubungan dengan susunan kata, kalimat rumpang karena penghilangan satu atau beberapa fungsi gramatikal, penggunaan ganda fungsifungsi gramatikal, dan kesalahan dalam penggunaan kata hubung.

Kemudian untuk melihat perubahan apa yang terjadi pada struktur kalimat yang bermasalah digunakan klasifikasi berdasarkan taksonomi strategi permu-kaan. Dari penggunaan klasifikasi tersebut dapat dilihat bahwa terjadi penam-bahan (addition), penghilangan (omission), kesalahbentukan (misformation), atau kesalahurutan (misordering) dalam kalimat yang memiliki sintaksis.

\section{Kesalahan pada Frase Kata Benda (Noun Phrase)}

\section{Kesalahan penggunaan determiners}

Kesalahan pada penggunaan determiners merupakan salah satu kesalahan yang banyak terjadi dalam tulisan mahasiswa. Kesalahan pada umunya berpusat pada artikel $a$ dan the. Dari 314 kesalahan yang ditemukan, 20\% adalah kesalahan penggunaan determiners atau sebanyak 63 kesalahan. Akan tetapi, dalam tulisantulisan tersebut kesalahan yang terjadi hanya berpusat pada penggunaan artikel $a$ dan the.

\section{Kesalahan penggunaan number}

Terdapat $15 \%$ atau 47 kesalahan dalam penggunaan number pada tulisan bahasa Inggris mahasiswa, 33 diantaranya merupakan kesalahan karena pensubtitusian kata benda jamak oleh kata benda tunggal dan 14 kesalahan merupakan kebalikannya, yaitu pensubtitusian kata benda tunggal oleh kata benda jamak.

\section{Kesalahan kata ganti}

Kesalahan penggunaan kata ganti ditemukan 31 kesalahan ditemukan pada beberapa kategori yaitu penghilangan relative pronoun, pensubtitusian relative pronoun, pensubtitusian pronoun subject, dan pensubtitusian pronoun object. Jumlah keseluruhan kesalahan dalam penggunaan pronoun adalah $10 \%$ dari total keseluruhan 314 kesalahan.

\section{Kesalahan dalam penggunaan preposisi}

Dari hasil penelitian ditemukan hanya 5\% dari seluruh kesalahan terdapat tiga jenis kesalahan yang berhubungan dengan penggunaan preposisi, yaitu penghilangan preposisi, penambahan preposisi, dan pensubtitusian preposisi. Jumlah total kesalahan 
dalam penggunaan preposisi adalah sekitar 16 kesalahan, diantaranya “...understand to the others ideas..." menjadi "...understand the others ideas..."

\section{Kesalahan dalam pengunaan kata benda}

Kata benda yang berdiri sendiri dapat pula dikategorikan sebagai frase kata benda. Kesalahan penggunaan kata benda yang dilakukan oleh mahasiswa berupa subtitusi pemilihan kata berjumlah 16 kesalahan atau 5\%. Contohnya, dalam bahasa Inggris kata cantik adalah beautiful yang merupakan kata sifat, sedangkan kata bendanya adalah beauty. Dilihat dari temuan-temuan kesalahan pada kategori frase kata benda, faktor yang menyebabkan kesalahan adalah interfensi. Sesuai dengan teori analisis kesalahan berbahasa yang menggunakan metode perban-dingan bahasa (Corder, 1981: 17). Alasan mengapa interferensi yang menjadi faktor penyebabnya adalah karena pembentukan struktur frase kata benda dalam bahasa Indonesia berbeda dengan bahasa Inggris. Dalam Bahasa Inggris terdapat poin-poin sintaksis yang tidak ada dalam bahasa Indonesia atau kalaupun ada, berbeda kondisi penggunaanya. Oleh karenanya, seperti yang dikatakan oleh Selinker (1972) kesalahan tersebut dapat dikarenakan transfer negatif bahasa sumber pada bahasa target atau disebut juga interferensi.

Kesalahan pembentukan frase kata benda karena generalisaasi yang ber- lebihan dapat diacukan salah satunya kepada penghilangan sufiks (-s/-es) pada kata benda jamak dalam kategori number. Berbeda kasusnya dengan kesalahan pada preposisi. Kategori preposisi dalam bahasa Inggris dan bahasa Indonesia tidak terlalu berbeda, hanya saja dalam bahasa Inggris, preposisi digunanakn pada saat tertentu. Oleh karenanya, banyak kesalahan karena faktor interferensi dari bahasa Indonesia. Taylor (1975) dan Corder (1981) menjelaskan hal tersebut sebagai kesalahan dalam penerjemahan. Misalnya, dalam tulisan bahasa Indonesia terdapat frase "berkaitan dengan...", maka dalam bahasa Inggris, banyak maha-siswa yang 
menerjemahkan menjadi "related with..", padahal frase yang benar adalah "related to...".

Selanjutnya, kesalahan dalam kategori pembentukan kata benda, faktor penyebab kesalahan tersebut adalah faktor intralingual. Hal tersebut dikarenakan mahasiswa harus mempelajari kata-kata secara terpisah dari pengetahuan bahasa pertanya karena sudah pasti jauh berbeda. Faktor lain yang menyebabkan kesalahan pada penggunaan frase kata benda adalah faktor intralingual mencakup beberapa aspek, akan tetapi dalam kasus kesalahan pada kata benda, aspek yang termasuk didalamnya yaitu, generalisasi yang berlebihan, pengabaian kaidah bahasa, dan penerapan kaidah yang tidak sempurna (Richards, 1984: 206).

\section{Kesalahan pada Frase Kata Kerja}

Kesalahan yang terjadi pada frase kata kerja yakni pada kategori kesalahan yang terjadi pada kata kerja yang berhubungan dengan struktur tenses yang meliputi kesalahan penghilangan dan penambahan be, verb agreement, dan kesalahbentukan kata kerja pada penggunaan tenses. Sedangkan kategori beri-kuntya adalah kesalahan yang terdapat dalam konstruksi khusus kata kerja tertentu dan bentuk to- infinitif dan gerund. Dari keseluruhan kesalahan 314 kesalahan mahasiswa, terdapat

$30 \%$ atau 94 kesalahan yang berhubungan dengan frase kata kerja.

Berdasarkan pada temuan-temuan dalam kesalahan pada kategori frase kata kerja, faktor yang menyebabkan kesalahan adalah overgeneralisasi dan inter-ferensi. Overgeneralisasi yang terjadi berhubungan dengan penggunaan basic verb. Hal tersebut dapat dilihat dari keseluruhan tenses yang mempunyai tendensi kesalahbentukan. Kebanyakan kesalahbentukannya digantikan dengan basic verb, padahal struktur tenses tertentu membutuhkan sufiks(-s) atau (-ed) pada peng- gunaan kata kerjanya. Hal tersebut dapat juga disebabkan karena basic verb merupakan unmarked form sedangkan penambahan sufiks-sufiks merubahnya menjadi marked form yang memang diakui sulit untuk dipelajari menurut teori pembelajaran bahasa kedua (Brown, 2007).

\section{Transformations}

Kesalahan transformations yaitu perubahan dalam pembentukan struktur kalimat pasif. Terdapat 5\% atau 16 kesalahan. Adapun contoh yang ditemukan 
disebabkan penghilangan kata kerja bantu be dan ada pula dikarenakan peng- hilanagn akhiran kata ed. Contoh kalimatnya yakni “...activities can do together...” menjadi "activities could be done together..."

\section{Miscellaneous}

Kesalahan miscellaneous sebanyak $10 \%$ atau 32 kesalahan ditemukan khususnya pada kategori word order, yakni kesalahan dalam mengurutkan kata. Adapun kesalahan yang ditemukan ialah kesalahan peletakan subjek dan kata kerja dalam satu klausa dan kesalahan mengurutkan peletakan head dan modifier. Berdasarkan kategori efek komunikasi, ditemukan pula kesalahan yang dilakukan oleh mahasiswa adalah sedikit kesalahan dan tidak ditemukan kesalahan yang menyeluruh, yakni walaupun mahasiswa menggunakan kalimat yang tidak sesuai dengan kaidah penulisan, maksud pesan dari tulisan tersebut masih bisa tersampaikan walaupun harus dengan menjawab dengan menggunakan interpretasi peneliti melalui konteks yang telah dibuat sebelumnya.

\section{SIMPULAN}

Kategori kesalahan yang digunakan yaitu kategori permukaan dan kategori efek komunikasi. Kesalahan-kesalahan yang ditemukan dalam kategori sintaksis dan permukaan berupa kesalahan pada noun phrase, verb phrase,transformation, dan miscellanous. Total jumlah kalimat yang tidak memenuhi kaidah penulisan ada sebanyak 128 kalimat, sedangkan total jumlah kesalahan yang ada dalam kalimat tersebut adalah 314 kesalahan. Kesalahan sintaksis yang paling dominan pada tulisan mahasiswa adalah kesalahan pada noun phrase yaitu sebanyak 55\% dengan determiners sebagai kesalahan yang paling banyak terjadi. Kemudian, pada kesalahan taksonomi permukaan yang paling banyak dilakukan mahasiswa adalah penghilangan dan penambahan. Adapun kesalahan yang ditemukan berdasarkan efek komunikasi adalah sedikit kesalahan dan tidak ditemukan kesa-lahan yang menyeluruh, yakni walaupun mahasiswa menggunakan kalimat yang tidak sesuai dengan kaidah penulisan, maksud pesan dari tulisan tersebut masih bisa tersampaikan.

\section{REFERENSI}

Brown, H. D. (2007). Principles of Language Learning and Teaching. EnglewoodCliffs, N. J: Prentice-Hall. 
Corder, S. P. (1981). The Elicitation of Interlanguage. IRAL. Special issue on the occasion of B. Malmberg's 60th birthday. (ed. G. Nickel).

Dulay, H. B. M. \& Krashen, S. (1982). Language Two. New York: Oxford University Press.

Chafe, W. (1982). Integration and Involvement in Speaking, Writing, and Oral Literature. In Tannen, D. Spoken and Written Language: Exploring Orality and Literacy. Norwood: Ablex.

Corder. (1981). Error Analysis and Interlanguage. Hongkong: Oxford University Press.

Creswell, J. W. (1994). Research Design: Qualitative and Quantitative Approaches London: SAGE Publications.

James, C. (1998). Errors in language learning and use: Exploring Error Analysis. London: Longman.

Richards, J. (1984). Error Analysis Perspective on Second Language Acquisition. Singapore: Longman.

Selinker, L. (1972). Interlanguage: An international review of applied linguistics. London. Longman.

Tarigan, H. G. (1998). Pengajaran Analisis Kesalahan Berbahasa. Bandung: Angkasa.

Taylor, B. P. (1975). The use of overgeneralization and transfer learning strategies by Elementary and Intermediate University student learning ESL. Washington DC: TESOL. 